\title{
Particle size and magnetic properties of Holocene estuarine deposits from the Doñana National Park (SW Iberia): evidence of gradual and abrupt coastal sedimentation
}

\author{
by \\ J. Lario, C. Zazo, A. J. Plater, J. L. Goy, C. J. Dabrio, F. Borja, F. J. Sierro \\ and L. LuQuE \\ with 7 figures and 1 table
}

Summary. High resolution particle size and environmental magnetic analyses were carried out on two cores from marsh sediments in the Doñana National Park (SW Spain), in an investigation of gradual and abrupt coastal change. Complementary palaeontological analyses were also undertaken. Whilst the balance between sea level change and fluvial sediment input is seen to have a strong influence on the gradual evolution of the Guadalquivir estuary, via the development and degradation of spit barrier systems, two episodes of abrupt environmental change are recorded by the input of coarser sediment to the back-barrier. These episodes would appear to be associated with high energy conditions as a result of storm or tsunami events. The multidisciplinary methodology presented here enables differentiation between these two episodes, the earlier of which (ca. $2400 \mathrm{yrBP}$ ) is probably due to a combination of enhanced erosion potential of the barrier and tsunami activity, and the later of which is the result of climatic instability during historical times (16th-18th centuries).

Zusammenfassung. Partikelgröße und magnetische Eigenschaften von Estuarinablagerungen aus dem Holozän im Nationalpark von Doñana (SW Iberia): Beweis für graduelle und abrupte Kïstensedimentation. - Im Rahmen einer Untersuchung über graduelle und abrupte Küstenveränderungen wurden Hochauflösungsanalysen bezüglich der Partikelgröße und magnetische Umgebungsanalysen in zwei Kernen aus Sumpfsedimenten im Nationalpark von Doñana (SW Spanien) vorgenommen. Zusätzliche paläontologische Analysen wurden ebenfalls durchgeführt. Während das Gleichgewicht zwischen den Veränderungen auf dem Meeresspiegel und der Zufuhr von Flußsedimenten, über die Entwicklung und den Abbau von Barrieresystemen wie Sandbänke, einen großen Einfluß auf die graduelle Evolution des Guadalquivir-Flußbettes zu haben scheint, werden zwei Episoden abrupter Umweltveränderung durch die Zuführung von rauherem Sediment in die hintere Barriere verzeichnet. Diese Episoden scheinen mit Bedingungen hoher Energie als Ergebnis eines Sturmes oder einer Tsunami zusammenzuhängen. Die multidisziplinäre Methodologie, die hier vorgestellt wird, ermöglicht eine Differenzierung zwischen diesen beiden Episoden, von denen die erste (ca. 2400 yrBP) wahrscheinlich auf eine Kombination von erhöhtem Erosionspotential der Barriere und der 'Tsunami-Aktivität zurückzuführen ist, und die zweite als Ergebnis klimatischer Instabilität während bestimmter historischer Abschnitte anzusehen ist (16.-18. Jahrhundert). 
Résumé. Taille et propietétés magnétiques de les dépôts de l'estuaire holocene du Parc National de Doñana (SW Iberia): évidence de sédimentation littoral brusque ou graduel. - Dans le Parc National de Doñana (SW d'Espagne), les carottes de deux sondages effectués dans la marais ont fait l'objet d'une détermination de taille et d'une analyse magnétique environnementale, et ce, dans le but de rechecher sur les échanges brusques ou graduels du littoral. Ce travail a été complété par une analyse paléontologique. Puisque le bilan entre las oscillations du niveau de la mer et la sédimentation fluvial a une influence considérable sur l'évolution de l'estuaire de Gualquivir, via le développement ou la dégradation de la barrière littōral, on a identifié deux épisodes d'échange environnemental avec l'enregistrement de sediments grossiers derrière la barrière. Ces épisodes sont liés à de fortes conditions hydrodynamiques, résultat de tempêtes ou de tsunamis. La méthodologie multidisciplinaire présentée dans ce rapport a permis de différencier entre ces deux épisodes; le premier (2,400 yrBP) est probablement dû à la combinaison de l'érosion potentielle et l'activité du tsunami, et le deuxième est le résultat d'instabilité climatique récent (16 ${ }^{\text {ème }}$ au $18^{\text {ème }}$ siècle).

\section{Introduction: the Guadalquivir marshland and barrier system}

The Donana National Park is situated in the mouth of the Guadalquivir river (SW Spain) and is characterised by marshland and an extensive spit barrier and dune complex. The Guadalquivir marshlands are the result of the progressive infilling of the Guadalquivir estuary during the Holocene due to the development and progradation of a spit barrier system at its mouth, as observed in most of the estuaries of this area (fig. 1). This sector of the coast is a wave-dominated, mesotidal environment with southwesterly prevailing winds and a west-to-east littoral drift that becomes reoriented to the south-east near the Strait of Gibraltar due to the orientation of the coast.

The study of the Holocene evolution of the Guadalquivir estuary and other adjacent estuaries (fig. 1) have been described by several authors (ZAZO et al. 1994, LARIo et al. 1995, Goy et al. 1996, LARIo 1996, LARIo et al. 1996, Rodriguez RAMIREz 1996, Rodriguez Ramirez et al. 1996, Dabrio et al. 1999), from which it has been possible to reconstruct the general pattern and sequence of Late Pleistocene and Holocene deposition.

Around ca. 18000 yrBP sea level was between -125 and $-120 \mathrm{~m}$ relative to the present level (Hernández Molina et al. 1994). This was followed by a rapid rise which started approximately ca. $16000-14000$ yrBP, when sea level was displaced by $100 \mathrm{~m}$ or so to about -25 to $-20 \mathrm{~m}$ by 9600 yrBP. This datum is recorded the base of the organic and peat deposits in cores from the Guadalete and Odiel estuaries (Dabrio et al. 1995, Goy et al. 1996, Lario 1996, Zazo et al. 1996a, Dabrio et al. 1999). From 9600 yrBP until at least ca. $8000 \mathrm{yrBP}$, a deceleration in the rate of sea level rise occurred, as recorded by the organic and peat deposits and shelly lags found in various cores (DABRIo et al. 1995, GoY et al. 1996). A change in the environmental magnetic properties and grain size parameters in these cores has been related to changes in the dynamics of the depositional environment (Lario 1996). The deceleration in sea-level rise to at least ca. 10000 yrBP has been related to the Younger Dryas event (LARIO 1997) and to the sea level stillstand that has been registered during this event in the North Atlantic (MAYEWSKI 1994, STANLEY 1995).

After $8000 \mathrm{yrBP}$, a renewed acceleration in the rate of sea level rise rate took place. In the estuaries of the Atlantic coast, maximum marine conditions were reached between 7600 and 7100 yrBP (Goy et al. 1996, DABRIo et al. 1999), and may 

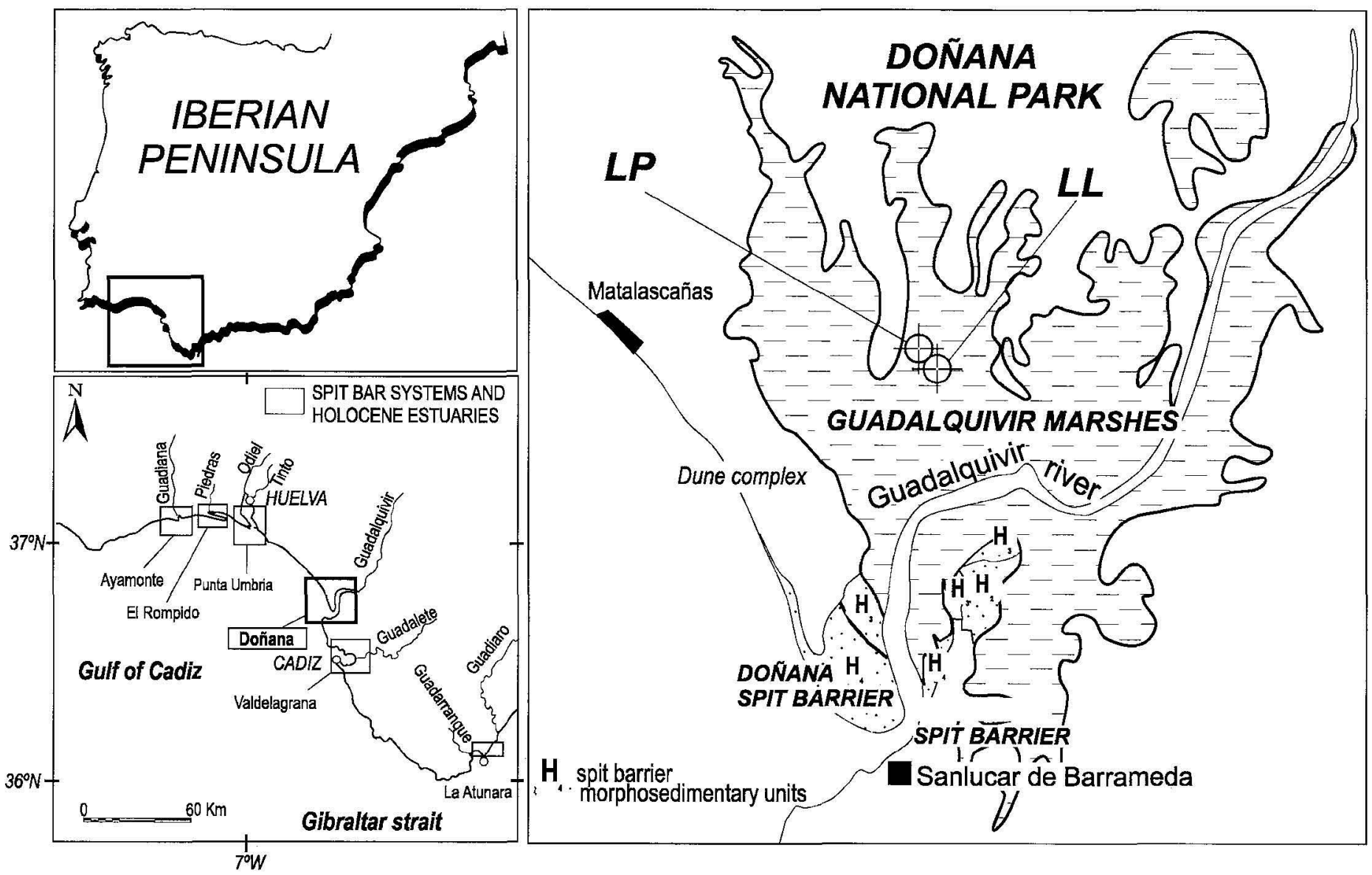

Fig. 1. Location of the study area and core sites. 
have continued until ca. 6800-6500 yrBP (LARIo 1996). At ca. 6500-6000 yrBP a further deceleration in the rate of sea level rise is recorded, or perhaps even a fall, as reflected in the input of river sediments to the coastal zone, which is identified from the environmental magnetic properties and grain size analyses carried out in sediments from Guadalete marshlands (Bay of Cadiz), as well as from a freshwater input as revealed by the isotopic signatures determined from analyses carried out on microand macrofauna from the same sediments (DABRIo et al. 1999).

As has been observed in the interpretation of some sea level curves from around the world, once the transgressive maximum is reached, a relaxation of the glacioeustatic component is produced and redistribution of oceanic water becomes the dominant factor influencing the nature of sea level change (Mörver 1994, 1996). This is responsible for the development of the morphosedimentary units present in this littoral area and, equally, for the evolution of coastal morphology. In this area, a series of negative and positive oscillations in sea level occurred and, together with the sedimentary dynamics at this time, favoured the development of spit barrier systems (ZAZO et al. 1994, LARIo et al. 1995). ZAZO et al. (1994) proposed that the progradation of the barriers developed in two main phases separated by a large erosional gap related to climatic instability. 'The first of these phases comprises morphosedimentary units $\mathrm{H}_{1}$ and $\mathrm{H}_{2}$, and the second is made up of units $\mathrm{H}_{3}$ and $\mathrm{H}_{4}$ (fig. 1). The morphosedimentary units consist of spit bar units that contain sets of beach ridges separated by large swales (i. e. gaps) or erosional surfaces that truncate beach ridges and swales. Radiocarbon data from this and later papers date the large erosional gap between the first and second progradation phases to between 2600 and $2350 \mathrm{yrBP}$ and at same time a change between agradation sedimentary conditions to progradation conditions have been also observed (Goy et al. 1996, ZAzO et al. 1996b). After this event, the second progradation phase started and the build up of large systems of spit barriers in the coastline reduced the connection of the estuary with the open sea. Simultaneously, the back-barrier evolved progressively through tidal lagoons to its present-day stage dominated by tidal flats and marshes (Goy et al. 1996). An erosional gap has also been identified in this second phase between morphosedimentary units $\mathrm{H}_{3}$ and $\mathrm{H}_{4}$, as defined by ZAzo et al. (1994), that has been dated to between 800 and 500 yrBP (GoY et al. 1996, LARIO 1996).

In addition to gradual change, the region is also susceptible to abrupt events. The Gulf of Cadiz is an area of high seismicity associated with the Azores-Gibraltar plate boundary that forms the westernmost part of the lithospheric boundary between the Eurasian and African plates. This boundary defines a zone of earthquake activity, aligned roughly east-west, that extends from the mid-Atlantic ridge near the Azores toward the Strait of Gibraltar (LOPEz Arroyo \& Udias 1972, Udias et al. 1976, BUFORN et al. 1988). Seismic events in this area are also responsible for the generation of tsunamis, which are recorded in both historical and modern instrumental data (Galbis 1932 1940, Mezcua \& Martínez 1983, Campos 1992). Several papers describe coastal changes generated by the tsunami associated with the 1755 AD Lisbon earthquake (MARTínez Solares et al. 1979, ANDRADE 1992, Dawson et al. 1995, DABRIO et al. 1997), but sedimentary and/or morphological records of other paleotsunamis have not yet been found in this region.

This paper focuses on the importance of low-frequency, high-magnitude events (storms and tsunamis) in the Holocene evolution of the Doñana coast. To this end, a 
multi-disciplinary methodology has been applied to the sedimentary record in the back-barrier in an attempt to distinguish between gradual and abrupt coastal change and, if possible, between the sedimentary record of storm surges and tsunami events.

\section{Methodology}

Two cores were obtained by means of an Eijkelkamp percussion drill and a Russian corer. Core LL (Lucio del Lobo) reached a depth of $7.30 \mathrm{~m}$ and core LP (Lucio del Pescador) extended to a depth of $7.60 \mathrm{~m}$ (fig. 1). Core LL was sampled every $20 \mathrm{~cm}$ and core LP every $10 \mathrm{~cm}$. High resolution particle size analysis was completed on these samples using a Coulter LS 130 laser sizer. The software provided by Coulter was used to calculate statistical parameters such as mean, mode and median using the arithmetic method (Coulter Corporation 1992). Measurements in SI units were converted into phi $(\phi)$ using the formula $\phi=-\log _{2} \mathrm{D}$ (grain diameter in $\mathrm{mm}$ ). Skewness, kurtosis and standard deviation (or sorting) were calculated using the methodology of FolK \& WARD (1957), once the grain sizes at the relevant percentiles given by the Coulter sizer were converted to phi. These parameters were then grouped into classes (McManus 1988) as summarised in table 1. Although no universal model exists to distinguish past depositional environments in sediments of this nature (McMANus 1988), it is generally accepted that mean grain size and sorting are hydraulically controlled (GRIFFITHS 1967) and can be positively correlated with energy of the environment and the degree of sediment processing (LONG et al. 1996), providing that there is no additional input of sediment or change in sediment provenance.

Table 1 Groups of particle size parameters following the criteria of McManus (1988).

Use of the parameters Parameters Notes

Measures of common size and average size

Measures of spread about the average

Measures of preferential spread to one side of the average mode median mean

sorting or graphic standard deviation mean/median

skewness

Measures of concentra- kurtosis tion or peakedness of the distribution of the grains to the central size
Reveals the symmetry of a granulometric distribution. Values between +0.1 to -0.1 show a symmetrical distribution. Negative and positive values are related to the amount of coarse or fine sediment tails

Well-sorted sediments present low values Well-sorted sediments present values $\approx 1$

Related both to the dispersion and the normality of the distribution. The use in geological interpretations is not clear (Boggs 1987) 


\section{LUCIO DEL PESCADOR (LP core)}

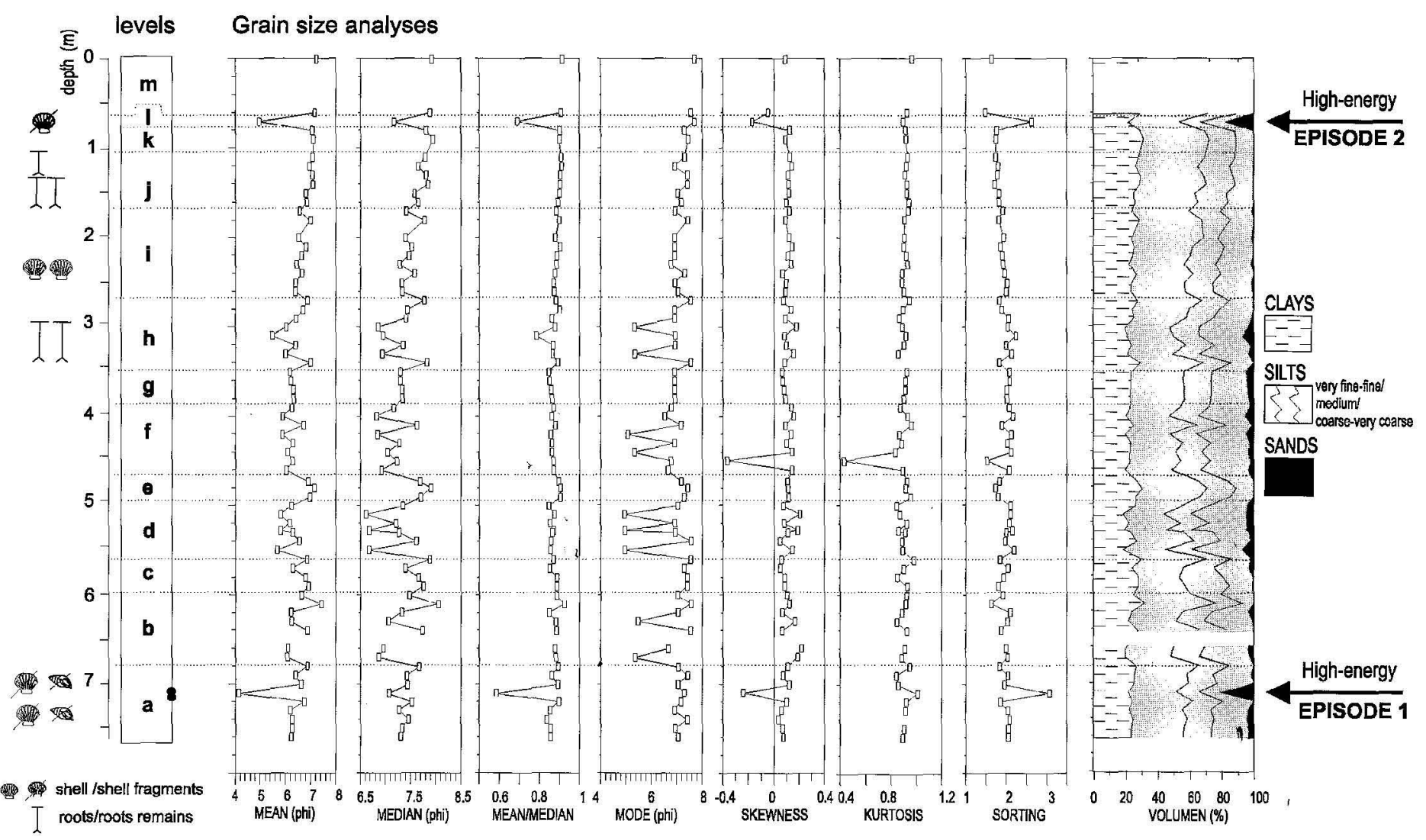


The magnetic properties measured in each sediment sample were magnetic susceptibility, anhysteretic remanent magnetisation (ARM), saturation isothermal remanent magnetisation (SIRM) and reverse field remanence measurements at $-20 \mathrm{mT}$, $-30 \mathrm{mT},-40 \mathrm{mT},-50 \mathrm{mT},-100 \mathrm{mT}$ and $-300 \mathrm{mT}$. Low- and high-frequency $(0.47$ and $4.7 \mathrm{kHz}$ ) magnetic susceptibility were measured with a Bartington MS2 susceptibility meter single-sample sensor. Fields of ARM were grown using a Molspin AF demagnetiser. The AF peak field was $100 \mathrm{mT}$ with a steady DC biasing field $0.04 \mathrm{mT}$. SIRM was generated in a Trilec pulse magnetiser with a field of $1000 \mathrm{mT}$. The reverse fields were generated in a Molspin pulse magnetiser. At each stage sample remanences were measured using a Minispin low speed fluxgate magnetometer. All these measurements were recalculated in relation to the weight of the sample and the following parameters and quotients were obtained: Magnetic susceptibility $(\chi)$, corresponding to the low frequency (LF) magnetic susceptibility; $\chi_{\mathrm{HF}}$ (high frequency magnetic susceptibility), $\chi_{\mathrm{FD}}$ and $\chi_{\mathrm{FD}} \%$ (frequency dependent magnetic susceptibility expressed as the difference between $\chi_{\mathrm{HF}}$ and $\chi_{\mathrm{LF}}$ as a mass-specific value and a percentage of $\chi_{\mathrm{LF}}: 100\left(\chi_{\mathrm{LF}}-\chi_{\mathrm{HF}} / \chi_{\mathrm{LF}}\right) ; \operatorname{SIRM} ; \chi_{A R M}$ (normalised anhysteretic remanent magnetisation); $\chi_{\mathrm{ARM}} / \mathrm{SIRM} ; \mathrm{SIRM} / \chi_{;}$SIRM/ $\chi_{\mathrm{ARM}} ; \chi_{\mathrm{ARM}} / \chi$; backfield IRMs (reverse field isothermal remanent magnetisations) expressed as a percentage of SIRM $\left(\mathrm{IRM}_{-20 \mathrm{mT}}, \mathrm{IRM}_{-30 \mathrm{mT}}, \mathrm{IRM}_{-40 \mathrm{mT}}, \mathrm{IRM}_{-50 \mathrm{mT}}, \mathrm{IRM}_{-100 \mathrm{mT}}, \mathrm{IRM}_{-300 \mathrm{mT}}\right)$; and HIRM (hard isothermal remanent magnetisation, being the difference between SIRM and IRM ${ }_{-300 \mathrm{mT}}$ ). The use and interpretation of these parameters have been largely described in previous literature (Thompson \& Oldfield 1986, Mafter 1988, OldField 1990, Hutchinson 1993, Peck et al. 1994, Stoner et al. 1996). The full range of magnetic data are presented in LARIO (1996), but here we focus on the parameters related to magnetic grain size, the concentration of magnetic minerals and mineralogy as used by Thompson and Oldfield (1986), Yu \& OldFreld (1989) and PECK et al. (1994).

\section{Lithological data and particle size analyses}

\subsection{Lucio del Pescador}

Based on the lithological section and grain-size analyses from core LP, the following levels have been differentiated (LARIO 1996) (fig. 2):

level m. (top of the core) Compact brown silty-clays.

level l. Thin $(\mathrm{mm})$ packages of carbonate sands and muds with remains of shell fragments. Presence of evaporites and iron oxides. A small change in grain size is represented in the mean and median, as well as poor sorting in the mean/median ratio, skewness and sorting.

level k. Homogeneous brown silty-clays. Homogeneity is recorded in all grain size parameters.

Fig.2. Grain size properties of core LP. Arrows show high-energy episodes. $(*)$ Black circles show samples for dating. Radiocarbon AMS dates in roots and shells at the same level are $2490 \pm 60 \mathrm{yrBP}$ (UtC-4026) and $2490 \pm 105 \mathrm{yrBP}$ (reservoir effect corrected, UtC-4031) respectively (modified from LARIO 1996). 
level $\mathbf{j}$. Violet clays with silt lenses. Intense root bioturbation and evidence of pseudogley and hydromorphism.

level i. Grey clays with millimetre-thick lenses of very fine sands and silts. Bivalve shell fragments are also present.

level h. Grey silty-clays characterised by scattered reduction spots at the base with fine parallel lamination. Intensive bioturbation in association with roots is present towards the top.

level g. Compact grey silty-clays. The homogeneity of this level is represented in all the grain size parameters.

level $\mathrm{f}$. Clays with some irregular silt lenses and fine horizontal lamination. A level with greater abundance of clays is represented by a decrease in the grain size (mean, median and mode). A sharp change in skewness, kurtosis and sorting at the bottom of this level is also observed.

level e. Clays with silt lenses and fine horizontal lamination. Well defined level in all the grain size parameters; homogeneous and well sorted.

level d. Alternations of silts and silty-clays with horizontal lamination. At the top there is a change to dark silts that include sand lenses. This alternation is well represented in the mean, median and mode grain size parameters.

level c. Silty level. Better sorting is illustrated by the mean of the mean/median ratio and sorting.

level b. Alternations of silts and homogeneous clays. At the bottom are some laminations of silt and fine sands.

level a. (bottom of the core). Clays with laminations of bivalve shell fragments and foraminifera. It is also possible to differentiate a level with reduction spots, and a sub-level $\left(\mathrm{a}_{1}\right)$ characterised by a small change in grain size skewness, kurtosis and sorting parameters.

\subsection{Lucio del Lobo}

Regrettably it was not possible to obtain a lithological section from this core, and the samples available for grain size analyses have not enabled a detailed record to be established. However, the characteristics of the measured grain size parameters show a similarity with the data from core LP (fig. 3). Near the base of the core $(7.00 \mathrm{~m}$ depth), a level that records an input of coarse sediments, most of them shell fragments, is observed. Between approximately 5 and $4 \mathrm{~m}$ depth there is evidence of episodes of dynamic instability, as revealed by an increase in coarse material and by bimodal grain size distributions. Similarly, there is an input of poorly-sorted coarse sediments at approximately 1.40 depth. This may well be related to storm events, but because coarser sediment influxes may also be due to changes in facies (i. e. channel migration), coupled with the fact that gradual lithological boundaries with the lower and upper units are recorded, the interpretation of a storm event is somewhat equivocal. Indeed, channel migration or reorganisation of fluvial network would also be induced by high energy episodes. 


\section{LUCIO DEL LOBO (LL core)}

\section{Grain size analyses}
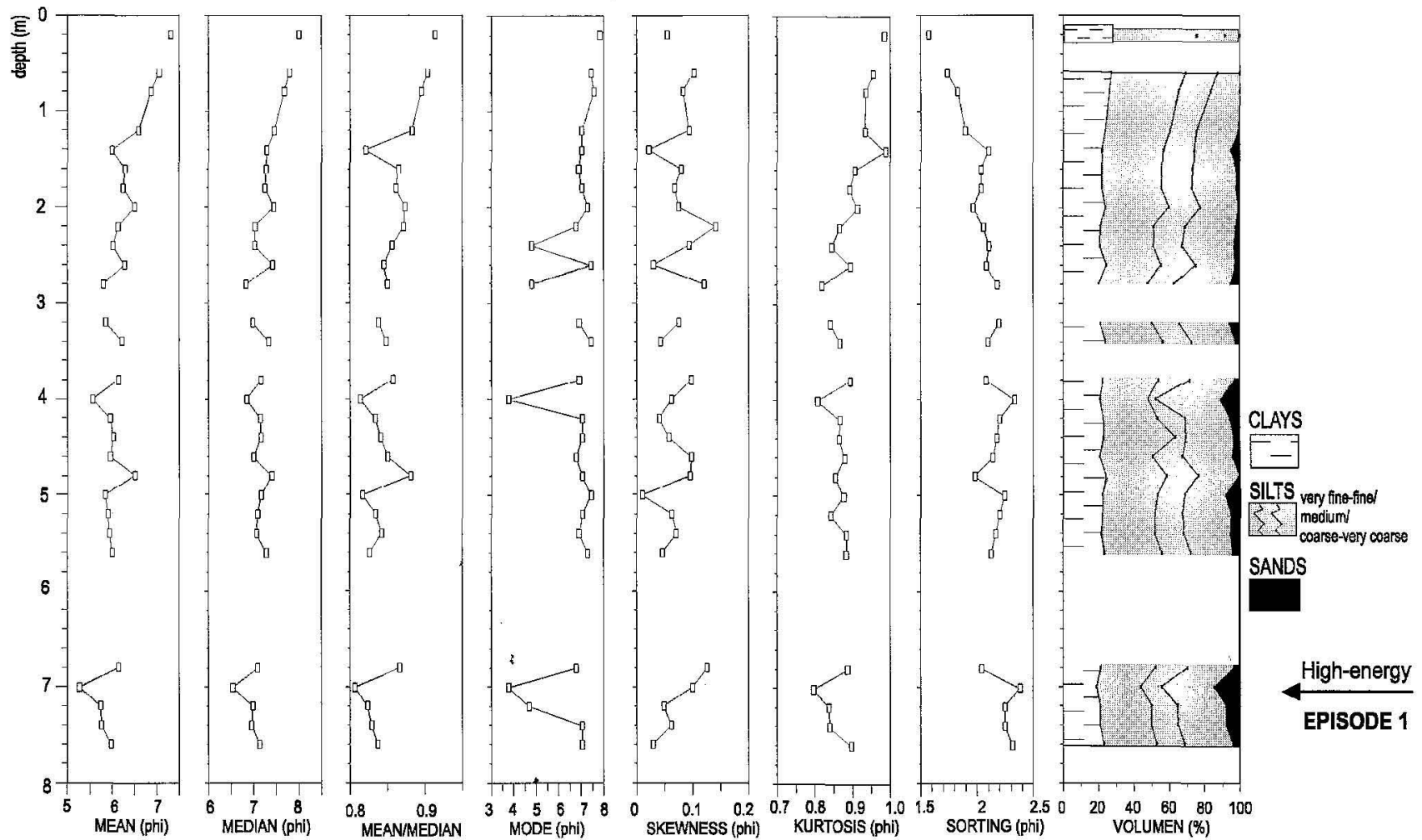

Fig. 3. Grain size properties of core LL (modified from LARIO 1996). 


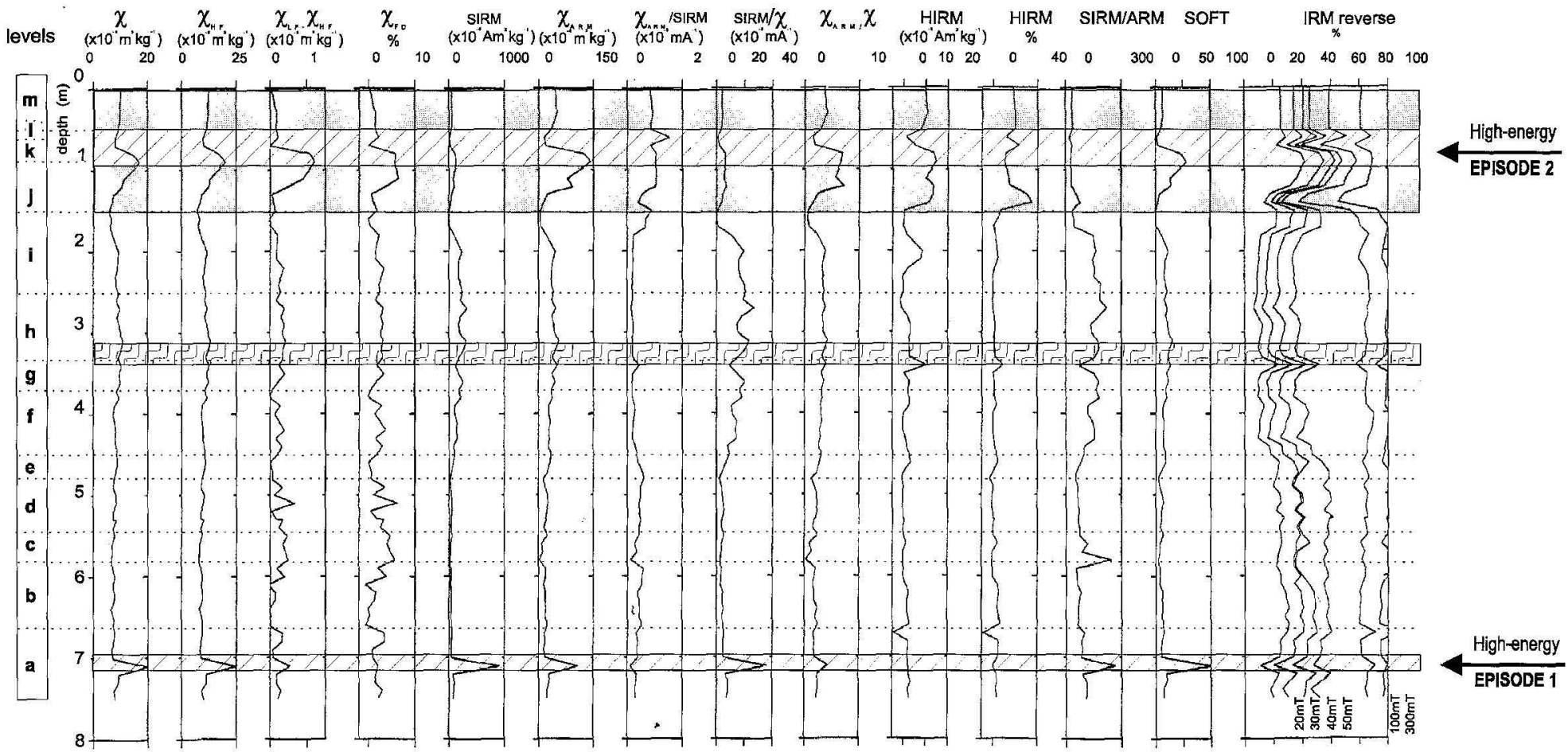

Fig. 4. Environmental magnetic properties of core LP, with high energy events being highlighted as in fig. 2 (modified from lLARIO 1996). 


\subsection{Lucio del Pescador}

The same levels as differentiated on the basis of the lithology and grain size characteristics can be recognised in some of the magnetic properties (fig. 4). Parameters related to magnetic grain size $\left(\chi, \chi_{\mathrm{FD}}, \mathrm{SIRM}, \chi_{\mathrm{ARM}}, \chi_{\mathrm{ARM}} / \mathrm{SIRM}\right.$ and $\left.\chi_{\mathrm{ARM}} / \chi\right)$ and mineralogy (SIRM, SIRM/ $\chi$, HIRM, Soft and IRM reverse fields) reveal the most prominent changes. At approximately $7.10 \mathrm{~m}$ depth there is an increase in magnetic properties related to an increase in the concentration of magnetic minerals, the majority of which would appear to be fine single domain grains, reflecting a change in the dynamics of the depositional environment and/or the provenance of sediment. However, the magnetic properties can also be influenced by diagenesis and authigenesis, as illustrated by the enhanced SIRM/ $\chi$ ratio and divergence of the reverse field IRM values in this level and, hence, the presence of authigenic greigite (OLDFIELD 1990). In our case this would appear to be associated with the high energy episode, as indicated by the particle size data, that occurred ca. $2400 \mathrm{yrBP}$, although it is more likely to be linked with the evidence of reductive diagenesis in level a. A subtle change in the magnetic properties (SIRM/ $\chi$, HIRM and IRM reverse), being more prominent in the parameters related to magnetic mineralogy (higher coercivity magnetic minerals such as haematite and goethite), is observed at a depth of ca. $3.5 \mathrm{~m}$. This coincides with the grain size and palaeontological data that record a change at this depth which is linked to the transition between a marine-influenced estuary and closed estuarine conditions, although a causal linkage is difficult to ascertain as the magnetic properties are very similar above and below this level. The enhanced contribution from higher coercivity magnetic minerals (HIRM) between a depth of $1.80 \mathrm{~m}$ and the top of the core may be related to soil development and hydromorphism processes. This sequence is interrupted by a period of enhanced magnetic concentration, characterised by a high proportion of very fine-grained superparamagnetic grains $\left(\dot{\chi}_{\mathrm{FD}}\right)$, indicating a marked change in sediment provenance which, coupled with the particle size data, may represent flooding of the upper soil horizon, probably due to storm and/or tsunami events.

\subsection{Lucio del Lobo}

A marked increase in the values of most of the magnetic parameters, characterised by an increase in the concentration of magnetic minerals and a significant contribution from fine magnetic grain sizes, is observed at a depth of $6.5 \mathrm{~m}$ which is associated, as in core LP, with high energy sedimentary events (fig. 5). Relative uniformity of the magnetic properties (even though there are some variations) is observed upward to a depth of about $3.50 \mathrm{~m}$. This is indicative of a change in sediment provenance and, coupled with the particle size data, in the energy of the deposition environment, probably due to the loss of a coastal sediment supply and to the predominance of river sediment input, as well as to the loss of coarse coastal sediments as opposed to fine-grained material. Like core LP, the increase in the contribution from high coercivity magnetic minerals and the reduction in the magnetic concentration (primarily fine single domain grains) between depths of 1.50 and $0.50 \mathrm{~m}$ can also be related to soil development and hydromorphism, although the high energy event 


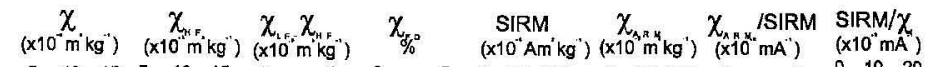
$\begin{array}{lllllllllllllllllll}5 & 10 & 15 & 5 & 10 & 15 & 0 & 1 & 0 & 5 & 0 & 125 & 250 & 0 & 100 & 200 & 0\end{array}$ 201020

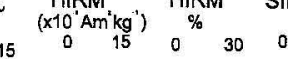

SIRM/ARM SOFT

Eิ 8

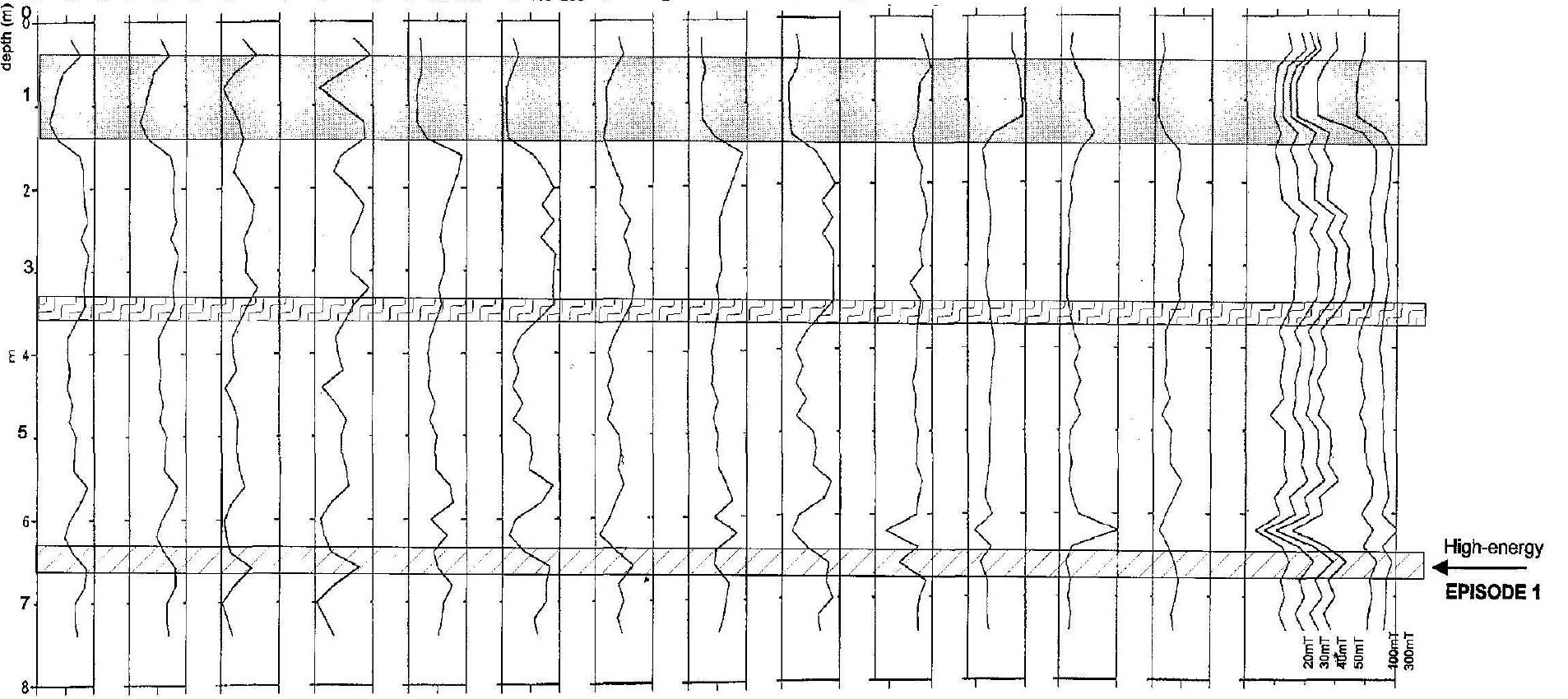

Fig. 5. Environmental magnetic properties of core LL (modified from LARIO 1996). 
recorded in core LP is not observed here (probably because this core was sampled every $20 \mathrm{~cm}$ ).

\section{Environmental interpretation and the relationship between the barrier and estuary infilling}

The plot of mean grain size against sorting (fig. 6a) reveals that most of the sediments have been deposited in a transitional environment between partially open estuary and closed basin conditions with a clear contribution of river input and sporadic high energy events (TANNER 1991, LARIO et al. 1996, LARIO 1996). This confirms that the estuary was becoming enclosed during this period, and that it is possible to associate this period of sedimentation with the second progradation phase observed in the spit barrier systems dated to between 2350 yrBP and present day. This agrees with previous studies which suggest that from ca. 2400 yrBP the progradation of the barrier pre vailed, with a progressive restriction in the communication with the open sea becoming more marked after ca. 800 yrBP (Goy et al. 1995, LARIo et al. 1996, ZAzo et al. 1996b).

A significant change in the depositional environment appears at a depth of about $6.5-7 \mathrm{~m}$, being characterised by relatively coarser sediment input and a change in the magnetic properties. This may be indicative of a possible fluvial contribution coupled with high-energy episodes that re-mobilised sediments and favoured the progradation of the barrier. Indeed, more sediment will have been included in the sediment budget from both fluvial input and erosion of the littoral units (sand cliffs, spit barriers) from the Algarve (South Portugal) and Gulf of Cadiz. Hence, the inner estuary became infilled via sediment entrapment. The relative uniformity of the measured parameters indicate continuous and stable sedimentation until a depth of approximately $4-3.50 \mathrm{~m}$, although minor variations enable the differentiation of smaller levels and short episodes of higher energy, as reflected in the grain size analyses by coarse material input. Between 3.5 and $2.70 \mathrm{~m}$ (dependent on which of the cores is considered), a significant change in fauna diversity and abundance have been also recorded (Goy et al. 1995). In both cores, remains of benthic and planktonic foraminifera, radiolarians, spicules of sponges, charophytes, ostracods, fragments and spicules of echinoderms, briozoans, bivalves and gastropods have been found, as well as frequent remains of plants. The presence of milliolids between depths of 3 and $5.50 \mathrm{~m}$ indicate a greater marine influence, since this group does not tend to be developed where there are restricted marine conditions. Planktonic foraminifera are relatively abundant in some samples, even though it is very probable that some of these are reworked, as is indicated by the poor state of preservation. A similar conclusion can be made from the scarce radiolarians that appear. Remains of echinoderms appear only between 3 and $5.50 \mathrm{~m}$, with a similar distribution to the milliolids, and appear to be related to an enhanced marine influence in the estuary. The sporadic presence of charophytes towards the top of the core LP indicates proximal conditions in the study area. From these data, it can be interpreted that the greatest marine influence occurred between 3 and $5.50 \mathrm{~m}$ depth. Below these levels the marine influence is less evident, even though the conditions were not so restricted as those registered above $3 \mathrm{~m}$, where estuarine conditions prevailed with only a very minor influence from the open sea. The reduction of autochthonous coccoliths in the 


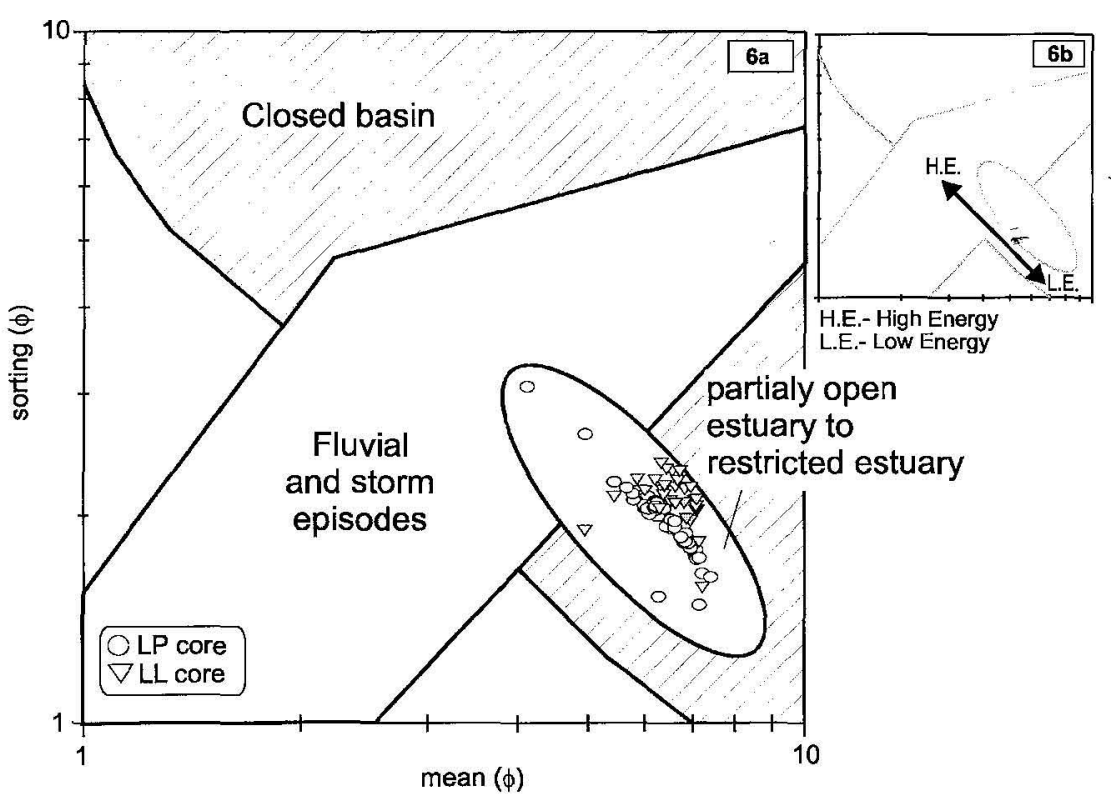

Fig. 6 a) Diagram of mean grain size versus sorting of sediments from cores LL and LP (modified from LARIO 1996). The sedimentary environments are modified from the classification of TANnER (1991). b) This should be also interpreted in terms of changes in the hydrodynamic conditions and energy of the depositional environment.

upper part of the core supports this progressive restriction in the open sea influence (LARIO 1996).

The changes in grain size and magnetic properties that appear at 4-3 $\mathrm{m}$ depth which are associated with a reduction in the marine influence, may be correlated with geomorphological changes observed at ca. $800 \mathrm{yrBP}$ in the spit barrier systems by LARIo et al. (1995) and Goy et al. (1996) that record a rapid development of these systems and, consequently, restriction in the back barrier environment. This is also related to a sudden marine fauna impoverishment and drop in diversity (Goy et al. 1995).

The relative uniformity in grain size parameters to a depth of approximately $1.50-1.00 \mathrm{~m}$ suggests a stability in the sedimentological conditions which correspond to a marsh system influenced by fluvial conditions characterised by distal flood-plain, distal crevasse-splay and levee sediments.

Moreover, a marked change in some magnetic parameters $\left(\chi, \chi_{\mathrm{FD}}, \chi_{\mathrm{ARM}}\right.$ and HIRM) observed between 1.50 and $0.50 \mathrm{~m}$ depth is indicative of a period of environmental stability associated with soil development and hydromorphism. In core LP, which is more influenced by channel dynamics, this level also contains an episode that represents an inwash of coarse material and dissection of the upper soil horizon. This may be associated with the high rate of sedimentation and barrier progradation related to flood and storm episodes which occurred from ca. $500 \mathrm{yrBP}$, and particularly during $16 \mathrm{th}, 17 \mathrm{th}$ and 18 th centuries (LARIo et al. 1996, ZAzo et al. 1996a). Final 
infilling of the estuary took place under comparatively stable conditions, but equally influenced by fluvial processes.

This interpretation can be correlated with the evidence obtained from the studies of the Doñana spit barrier system (ZAZO et al. 1994, LARIo et al. 1995). Of the three morphosedimentary units observed in the Atlantic area $\left(\mathrm{H}_{2}, \mathrm{H}_{3}\right.$ and $\left.\mathrm{H}_{4}\right)$, the two most recent units are recorded in Doñana, corresponding to the second progradation phase, and all three units are present in La Algaida. As noted previously, a large erosional gap can be identified over the entire region. This is dated to between 2600 and $2350 \mathrm{yrBP}$ and is probably a consequence of a moderate sea level rise, perhaps linked with climatic instability and storm episodes (ZAZO et al. 1994, LARIO 1996). These events would be the cause of the degradation of unit $\mathrm{H}_{2}$. At $4.00-3.50 \mathrm{~m}$ depth in the cores, it would seem be that at least unit $\mathrm{H}_{3}$ came to an end and, consequently, the communication with the open sea was severely restricted. The almost total infilling of the estuary promoted the formation of hydromorphic soils during the last millennium. At the same time, the barrier continued to prograde, forming unit $\mathrm{H}_{4}$ and acting as a littoral sediment trap for the resulting spit barrier. In the areas most influenced by fluvial conditions (core LP, figs. 2 and 4), a period of climatic instability, dated to $400-500 \mathrm{yrBP}$, can also be identified as an episode that interrupted the phase of hydromorphic soil development via the input of coarser sediment of different provenance.

\section{Episodes of coarser sediment input}

As the bottom of core LP has been dated to ca. $2500 \mathrm{yrBP}$ (Goy et al. 1996; fig. 2), the sedimentary sequence registered in the cores encompasses the second progradation phase recorded in this littoral area. From the interpretation of particle size analyses, some episodes of coarser sediment input to the inner estuary during this infilling phase have been recognised (LARIO 1996, LaRIO et al. 1996). These episodes are characterised by an increase in the mean grain size (fig. 2 and 3). The mean/median ratio, usually with values close to unity (indicating well sorted sediments), reveals a marked decrease in sorting at this time. Skewness, sorting and, to a lesser extent, kurtosis also reveal a marked change in environment at these levels. These granulometric characteristics are typically bimodal distributions, as can be confirmed once the particle size distribution diagrams of the samples are investigated (fig. 7). These particle size signatures are clearly identified in core LP, but they can only be inferred to be so for core LL because it lacks the necessary resolution.

Episode 1 (located at ca. $7 \mathrm{~m}$ depth, figs. 2 and 3 ) presents the enhanced input of coarser sediment, marked by an increase of silt and fine sand, as well by the presence of marine shell fragments that were separated with a $740 \mu \mathrm{m}$ sieve before use of the Coulter sizer. Episode 2 (located at $0.70 \mathrm{~m}$ depth in core LP and probably at ca. $1.20 \mathrm{~m}$ in core LL, figs. 2 and 3) also displays these granulometric characteristics, but they are less marked and shell fragments are not present. As noted previously, these characteristics are indicative of an increase in the hydraulic energy of the depositional environment. A bivariate plot of mean grain size versus sorting, interpreted only in terms of change of the hydrodynamic conditions (fig. 6b), reveals that these coarse grained units were deposited under different hydrodynamic and energy conditions than the remainder of the core. Changes in magnetic properties are also registered in 


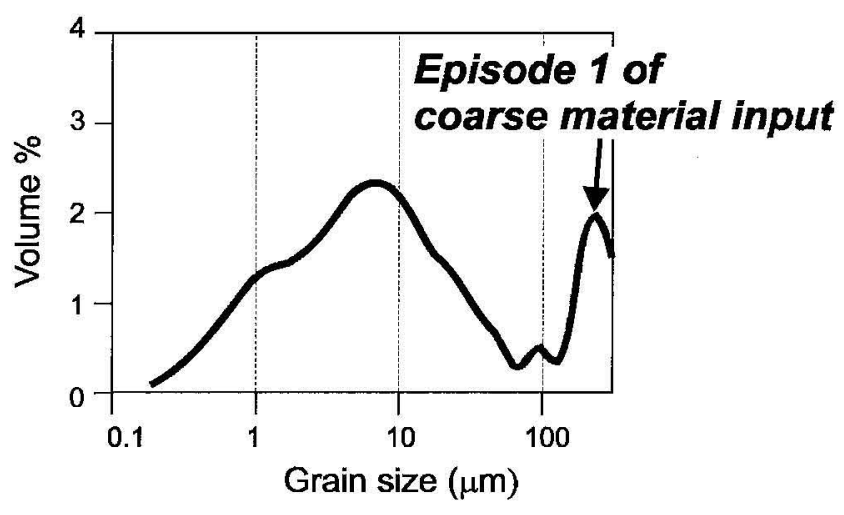

\section{Sample LP-5 (0.7 m depth)}

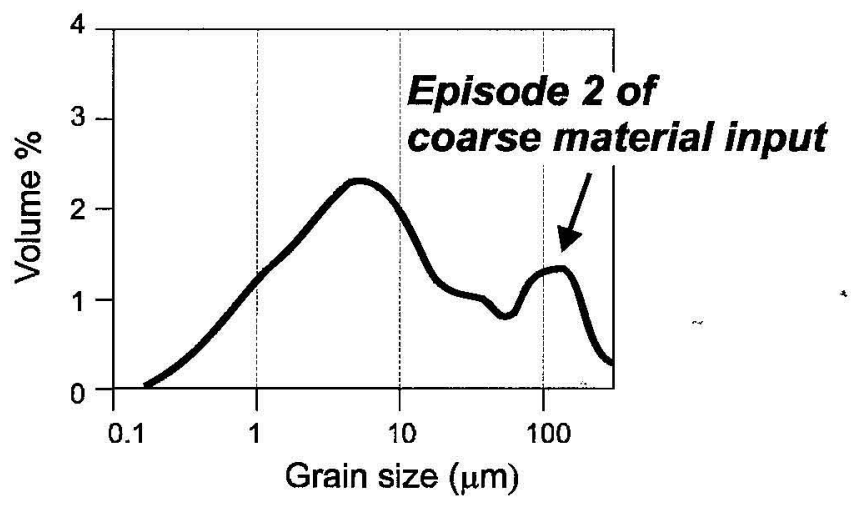

Fig. 7. Diagram of particle size analyses distribution of episodes identified in fig. 2. The bimodal distributions reflect the input of coarse sediment (arrows) associated with the high energy of these events.

the same levels (figs. 4 and 5). The magnetic properties of the sediments are controlled by the composition, concentration and grain size of magnetic minerals and reflect subtle lithological variations which can be interpreted in terms of changes in the dynamics of the depositional environment (STONER et al. 1994, STONER et al. 1995). Also, these changes may reflect variations in sediment provenance and/or transport processes, as well as diagenetic overprinting of the detrital magnetic signature (STONER et al. 1996). Moreover, an increase in susceptibility and remanent intensity often correspond to obvious lithological changes (SutTull et al. 1982). Episodes 1 and 2 show a marked change in most magnetic properties, which are interpreted in terms of changes in sediment source and depositional energy. After the high energy Epi- 
sode 1 , the previous magnetic characteristics become re-established and reveal it as a sporadic episode not likely to be related to changes in sea level or sediment budget. In core LL, a marked change in magnetic mineralogy is observed at $6.2 \mathrm{~m}$ depth, but this magnetic signature seems to be related to the presence of greigite (OLDFIELD 1990). The magnetic properties related to Episode 2 are more complex, but this episode may be linked to changes in the upper sedimentary units (between 1.60 and $0.40 \mathrm{~m}$ depth) that seem to be related to the development of hydromorphism features in the soils and to flood episodes that occurred in historical times (principally during 16 th, 17 th and 18 th centuries) during periods of climatic instability, as is supported by historical data (BORJa 1992).

From palaeontological analyses it would appear that Episode 1 of coarse sediment influx (at ca. $7.10 \mathrm{~m}$ in core LP) is related to the input of shell fragments and an increase in echinoderm fragments. After this episode, communication with the sea was re-established, as revealed by the presence of brackish species of foraminifera and diatoms (LARIO 1996). At ca. 4-3 m depth, every trace of marine conditions disappears and the total infilling of the estuary under marsh conditions would appear to have taken place.

Episode 1, centred around $2400 \mathrm{yrBP}$ (ca. 2600-2500 CalBP), is clearly of marine origin and is probably associated with the high energy erosion episode that has been recorded in all the spit barrier systems from this littoral zone as a large erosional gap between different morphosedimentary units (ZAZO et al. 1994, LARIo et al. 1995, GoY et al. 1996, Lario 1996). This episode is accompanied not only by input of silt and coarse sediments (that exhibit bimodal and multimodal particle size distributions), as has been observed by Dawson et al. (1995) in the Algarve (S Portugal), but also by the presence of shell fragments. Although the presence of multimodal particle size distributions or the input of coarse sediment provides a contradictory record in the study of tsunami events (Srr et al. 1995, DAwsonet al. 1996), Dawson et al. (1995) found sedimentary units which they interpreted as tsunami deposits to be extremely rich in shell fragments.

RoDriguez Ramirez et al. (1996) described a phase of extensive erosion in the Doñana spit barrier between the $\mathrm{H}_{2}$ and $\mathrm{H}_{3}$ morphosedimentary units described by ZAzo et al. (1994). This resulted in erosion of the Doñana $\mathrm{H}_{2}$ and the isolation of the La Algaida $\mathrm{H}_{2}$ morphosedimentary units. Moreover, LARIO (1996), in the nearby spit barrier system of Punta Umbria (fig. 1), found that a similar episode linked with a large erosional gap dated to between 2600 and 2350 yrBP (2700-2400 CalBP) was responsible of the segmentation of the spit and the initiation of a new drainage system (Punta Umbria ria) that allowed the installation of the Roman fisheries. Due the breakdown of the spit barrier, marine conditions were re-established in the estuary, with an increase in fauna diversity and abundance (Goy et al. 1996). There is some evidence to suggest that large-scale tsunamis are often associated with profound reorganisation of coastal barrier systems (BourrouIlH-Le JAN \& TALANDIER 1985, DAWSON 1994). ANDRADE (1992) found that tsunami inundation in the Algarve region, associated with the Lisbon earthquake of $1755 \mathrm{AD}$, appears to have been accompanied by widespread submergence, barrier breaching and the deposition of a large washover fan, as well as the complete reorganisation of the back-barrier drainage system. Also associate with the 1755 Lisbon earthquake Dabrio et al. (1998) found the same features affecting the Valdelagrana spit barrier (Gulf of Cádiz, fig. 1). 
Even though all the morphosedimentary units of the spit barrier systems are separated by an erosional gap, as has been observed in several geomorphologic studies (ZAZO et al. 1994, LARIO et al. 1995, LARIO 1996), there is no record of this erosional hiatus in cores from the back-barrier. However, the erosional gap dated between 2600 and $2350 \mathrm{yrBP}$ appears to be formed by the conjunction of various situations that provoked this event. Taking the evidence for a significant reorganisation of coastal barrier system into account, there are indications of the occurrence, perhaps co-incident with a period of storm activity, of a very rapid high energy episode such a tsunami event. This tsunami may not have been recorded as a consequence of its magnitude, but rather as a result of the specific erosional conditions at this time. This is supported by erosional conditions, linked with climatic instability (storm episodes) and slow sea level rise, that have been recorded over the entire south Iberian littoral, not only in the Atlantic area that has been cited previously, but also in the Mediterranean area (Goy et al. 1986, Somoza et al. 1991, ZAZo et al. 1994, ZAzo et al. 1996b). Historical data reveal that an earthquake in the Gulf of Cadiz took place near the time of this episode, at 600 BC (GALBIS 1932, CAmpos 1992), but the first one noted in the historical record of tsunamis took place at 218 BC (GALbis 1932) and has been described by the same author as:

“...la isla de Cádiz y toda la Marina frontera de Andalucía padeció grandes terremotos o temblores [...] la mar anegó muchos lugares que primero fueron descubiertos lanzando fuera de si multitud de pescados, unos comunes, y otros nunca vistos."

("...The Island of Cadiz and all the Andalucian marine boundary suffered large earthquakes and shakes [...] the sea flooded a lot of sites that before it were uncovered throwing up a multitude of fishes, some of them common and well known and others never seen.")

\section{Conclusions}

High resolution particle size analyses and environmental magnetic analyses have proved valuable tools in the identification of both gradual and abrupt changes in the deposition of estuarine sediments, particularly in terms of hydrodynamic conditions and depositional energy. Classification of these sediments by means of a combination of grain size data enable us to place the sequence obtained from the Doñana cores at a transition between a partially closed estuary to a restricted and infilled estuary, which corresponds with the regional sequence observed in other estuaries in the region during the Late Holocene (ca. $2500 \mathrm{yrBP}$ to the present). In these sequences, rapid episodes of coarser sediment input have been recognised, which may be related to high energy events. Changes in the magnetic properties also reveal simultaneous changes in sediment provenance and processing.

High energy storm and tsunami episodes will leave similar sedimentary signatures in coastal deposits, but the combination of particle size analyses, environmental magnetic analyses, and geomorphological interpretation enable differentiation between the two high energy episodes observed. In the Atlantic Iberian littoral, a record of tsunami activity at ca. $2400 \mathrm{yrBP}$ has been recorded as a rapid erosional episode. However, this erosion potential has been amplified by the simultaneous occurrence of coastal erosion linked with climatic instability and a slight rise in sea level rather than as a consequence of tsunami magnitude. 
The authors should like to acknowledge financial support from Spanish DGICYT Projects PB95-109 and PB95-946 and DGES Projects PB98-514 and PB98-265 and Fundación Areces Project "Cambios climáticos y variaciones del nivel del mar..." This research is also a contribution to IGCP Project 437 and the INQUA Shorelines Commission.

\section{References}

Andrade, C. (1992): Tsunami generated forms in the Algarve barrier islands. - Science of Tsunami Hazards 10: 21-33.

Boggs, S. (1987): Principles of sedimentology and Stratigraphy. - Mernil Publish. Company, Ohio, 784 pp.

BorJA, F. (1992): Cuaternario reciente, Holoceno y periodos históricos del SW. de Andalucía. Paleogeografía de medios litorales y fluvio-litorales de los últimos 30.000 años. Ph. D. Thesis, Universidad de Sevilla, 469 pp.

Bourrouilh-Le Jan, F.G. \& J.Talandier (1985): Sédimentation et fracturation de hautes énergie en milieu récifal: tsunamis, ouragans et cyclones et leurs effects sur la sédimentologie et la géomorphologie d'un atoll: motu et hoa, à Rangiroa, Tuamotu, Pacifique SE. - Marine Geology 67: 263-333.

Buforn, E., A. Udias \& M. Colombas (1988): Seismicity source of the mechanic of the Azores-Gibraltar plate boundary. - Tectonophysics 152: 89-118.

Campos, M.A. (1992): El riesgo de tsunamis en España. Análisis y valoración geográfica. Monografias Instituto Geografico Nacional, 9: 204pp.

Coulter Corporation (1992): Coulter LS, User Manual.

Cowel, P.J. \& B.G. Thом (1994): Morphodynamics of coastal evolution. -In: CARTER, R. W. G. \& C.D. Woodroffe (eds.): Coastal evolution: Late Quaternary shoreline morphodinamics: 33-86; Cambridge Univ. Press, Great Britain

Dabrio, C.J., J.L. Goy, J. Lario, C. Zazo, F. BorJa.\& A. GonzÁlez (1995): The Guadalete estuary during the holocene times (Bay of Cadiz, Spain). - INQUA Mediterranean and Black Sea Shorelines Subcom. Newsletter 17: 19-22.

Dabrio, C.J., J.L. GoY \& C. ZAZO (1998): The record of the tsunami produced by the 1755 Lisbon earthquake in Valdelagrana spit (Gulf of Cádiz, southern Spain).- Geogaceta 23:31-34.

Dabrio, C. J., C. Zazo, J. L. Goy, F.J. Sierro, F. Borja, J. Lario, J. A. González \& J. A. FloRES (1999): Depositional history of estuarine infil during the Late Pleistocene-Holocene postglacial transgression. - Marine Geology 162 (2/4): 381-404.

Dawson, A. G. (1994): Geomorphological effects of tsunami run-up and backwash. - Geomorphology 10: 83-94.

Dawson, A. G., R. Hindson, C. Andrade, C. Freitas., R. Parish \& M. Bateman (1995): Tsunami sedimentation associated with the Lisbon earthquake of 1 November AD 1755: Boca do Rio, Algarve, Portugal. - The Holocene 5 (2): 209-215.

Dawson, A. G., S. Shi, S. Dawson, T. Takamashi \& N. Shuto (1996): Coastal sedimentation associated with the June 2nd and 3rd, 1994 tsunami in Rajegwesi, Java. - Quatern. Science Rev. 15: 901-912.

FOLK, R. L. \& W.C. WARD (1957): Brazos River bar: a study in the significance of grain size parameters. - J. of Sedim. Petrol. 31: 514-529.

Galbis, J. (1932): Catálogo sismico de la zona comprendida entre los meridianos $5^{\circ} \mathrm{E}$ y $20^{\circ} \mathrm{W}$ de Greenwich y los paralelos $45^{\circ}$ y $25^{\circ} \mathrm{N}$. - Dirección General del Instituto Geog., Catastral y de Estadística, Madrid, Tomo I, 807 pp. 
GalBIS, J. (1940): Catálogo sismico de la zona comprendida entre los meridianos $5^{\circ} \mathrm{E}$ y $20^{\circ} \mathrm{W}$ de Greenwich y los paralelos $45^{\circ}$ y $25^{\circ} \mathrm{N}$. -Dirección General del Instituto Geog. y Catastral , Madrid, Tomo II, $277 \mathrm{pp}$.

Gơ, J. L., C. Zazo, C. J. Dabrio \& C. Hillaire Marcel (1986): Evolution des systèmes de lagons-îles barrière du Tyrrhénien a l'actualité a Campo de Dalías (Almerỉa, Espagne). Edit. de l'Orstom, Coll. Travaux et Documents 197: 169-171.

Goy, J. L., C. Zazo, C. J. Dabrio, J. Lario, F. BorJa, F. Sierro \& J. A. Flores (1995): Global and regional factors controlling changes of coastlines in southern Iberia during the Holocene. - In: Late Quaternary Coastal records of rapid change: Application to present and future conditions. IGCP Project 367, IInd Annual Metting, Antofagasta, Chile, November 1995. Abstr. vol. 37-38.

- (1996): Global and regional factors controlling changes of coastlines in southern Iberia during the Holocene. - Quaternary Science Reviews 15 (3-4): 1-8.

GriffTTHS, J. C. (1967): Scientific method in analysis of sedimentary environments. - McGrawHill, New York.

Hernández Molina, F. J., L. Somoza, J. Rey \& L. Pomar (1994): Late Pleistocene-Holocene sediments on the Spanish continental shelves: Model for very high resolution sequence stratigraphy. - Marine Geology 120: 129-174.

Hutchinson, S. (1993): The magnetic record of particulate pollution in a saltmarsh, Dee Estuary, UK. - The Holocene 3 (4): 342-350.

Lario, J. (1996): Ultimo y Presente Interglacial en el área de conexión Atlántico - Mediterráneo: Variaciones del nivel del mar, paleoclima y paleoambientes. $-\mathrm{Ph}$. D. Thesis. Universidad Complutense de Madrid: 269 pp.

- (1997): Is the Younger Dryas recorded in the estuarine sediments from south western Iberia Peninsula? - INQUA Mediterranean and Black Sea Shorelines Subcom. Newsletter 19: $56-63$.

Lario, J., C. Zazo, C.J. Dabrio, L. Somoza, J. L. Goy, T. Bardají \& P. G. Silva (1995): Record of Recent Holocene Sediment Input on Spit Bars and Deltas of South Spain. - In: Core, B. (ed.), Holocene Cycles: Climate, Sea Levels, and Sedimentation. J. of Coastal Research, Special Issue 17: 241-245.

Lario, J., C. Zazo, A. J. Plater, J. L. Gox, C. Dabrio \& F. Borja (1996): Late Holocene evolution of the Guadalquivir marshes (SW Spain). - 28th International Geographical Congress, The Hague, August 1996. Abstr. vol. 249.

Long, A., A. J. Plater, M. P. WAller \& J. B. Innes (1996): Holocene coastal sedimentation in the Eastern English Channel: New data from the Romney Marsh region, United Kingdom. - Marine Geology 136: 97-120.

Lopez Arroyo, A. \& A. Udias (1972): Aftershock sequence and focal parameters of the February 28, 1969 earthquake of the Azores-Gibraltar fracture zone. - Bull. of the Seismological Soc. of America 62 (3): 699-72J.

MAHeR, B.A. (1988): Magnetic properties of some synthetic sub-micron magnetites. - Geophys. J. Royal Astr. Soc. 94: 83-96.

Martinez Solares, J. M., A. Lopez Arroyo \& J. Mezcua (1979): Isoseismal map of the 1755 Lisbon earthquake obtained from Spanish data. - Tectonophysics 53: 301-313.

Mayewski, P.A.(1994): The Younger Dryas as viewed through the Summit Greenland ice cores. - PAGES: News Int. Paleosci. Commun. 2 (2): 3-4.

McManus, J. (1988): Grain Size determination and interpretation. - In: Tucker, M. (ed.): Techniques in Sedimentology: 63-85; Blackwell Sc. Publ.

Mezcua Rodriguez, J. \& J.M. Martinez Solares (1983): Sismicidad del Area IberoMogrebí. - Instituto Geográfico Nacional, Publicación 203: 301 pp.

Mörner, N.A. (1994): Recorded sea level variability in the Holocene and expected future changes. - Bull. INQUA Neotectonic Commission 17: 48-53.

(1996): Sea Level Variability. - Z. Geomorph. N.F 102: 223-232. 
Oldfield, F. (1990): Magnetic measurement of recent sediments from Big Moose Lake, Adirondack Mountains, N. Y., USA. - J. of Palaeolimnol. 4: 93-101.

Peck, J. A., J. W. King, S. M. Colman \& V. A. Kravchinsky (1994): A rock-magnetic record from Lake Baikal, Siberia: Evidence for Late Quaternary climate change. - Earth and Planetary Science Letters 122: 221-238.

Rodríguez Ramírez, A., J. Rodríguez Vidal, L. Cáceres, L. Clemente, G. Belluomint, L. Manfra, S. Improta \& J.R. De Andrés (1996): Recent coastal evolütion of the Doñana National Park (SW Spain). - Quaternary Science Reviews 15 (8-9): 803-809.

SHI, S., A.G.Dawson \& SMith, D.E.(1995): Coastal sedimentation associated with the December 12th 1992 tsunami in Flores, Indonesia. - Pure and Applied Geophysics 144: 525-536.

Somoza, L., C. Zazo, J. L. Goy \& V. Díaz del Río (1991): Sea-level fluctuation cycles in the Mediterranean Spanish coast during the last 7,000 years. Applications as a forecasting model for future sea-level trend. - In: Meeting on the Ocean Change. Management Patterns and the Environment. Huelva, Spain: La Rábida, Abstracts: 19-26.

Southon, J. R., D. E. Nelson \& J.S. Vogel (1990): A record of past ocean-atmosphere radiocarbon differences from Northeast Pacific. - Paleoceanography 5 (2): 197-206.

STANLEY, D.J. (1995): A global sea-level curve for the late Quaternary: the impossible dream? - Marine Geology 125: 1-6.

Stoner, J. S., J. E. T. Channell \& C. Hillaire-Marcel (1995): Late Pleistocene relative geomagnetic paleointensity from the deep Labrador Sea: Regional and global correlations. Earth and Planetary Science Letters 134: 237-252.

(1996): The magnetic signature of rapidly deposited detrital layers from the deep Labrador Sea: Relationship to North Atlantic Heinrich layers. - Paleoceanography 11 (3): 309-325.

Stoner, J. S., J. E. T. Channell, C. Hillatre-Marcel \& J. C. Mareschal (1994): High resolution rock magnetic study of a Late Pleistocene core from the Labrador Sea. Can. J. Earth. Sci. 31: 104-114.

Suttill, R. J., P. Turner, P. \& J. Vaughan (1992): The geochemistry of iron in Recent tidalflat sediments of the Wash area, England: a mineralogical, Mössbauer and'magnetic study. - Geochimica et Cosmochimica Acta 46: 205-217.

TANnER, W. F. (1991): Application of suite statistics to stratigraphy and sea-level changes. - In: Syvitski, J.P.M. (ed.): Principles, methods and applications of particle size analysis: 283-292; Cambridge Univ. Press.

Thompson, R. \& F. Oldfield (1986): Environmental Magnetism. - Allen \& Unwin, London, 285 PP.

Udias, A., A. López Arroyo \& J. Mezcua (1976): Seismotectonics of the Azores-Alboran region. - Tectonophysics 31: 259-289.

Yu, L. \& F. OLDFIELD (1989): A multivariate mixing model for identifying sediment source from magnetic measurements. - Quatern. Res. 32: 168-181.

Zazo, C., J. L. Goy, J. Lario \& P. G. Silva (1996a): Littoral Zone and Rapid Climatic Changes during the Last 20,000 years, The Iberia Study Case. - Z. Geomorph. N. F.102: 119-134.

Zazo, C., J. L. Goy, L. Somoza., C.J. Dabrio, G. Belluomini, S. Impronta, J. Lario, T. Bardají \& P. G. Silva (1994): Holocene sequence of relative sea level highstand-lowstand in relation to the climatic trends in the Atlantic-Mediterranean linkage coast: Forecast for future coastal changes and hazards. - J. of Coastal Research 10 (4): 933-945.

Zazo, C., C. J. Dabrio, J. L. Goy, T. Bardaji, B. Ghaleb, J. Lario, M. Hoyos, C. HillatreMarcell, F. Sierro, J. A. Flores, P. G. Silva \& F. Borja (1996b): Cambios en la dinámica litoral y nivel del mar durante el Holoceno en el sur de Iberia y Canarias Orientales. - Geogaceta 20 (7): 1679-1682. 
Addresses of the authors: J. Lario, C. Zazo \& L. Luque, Dep. Geología, Museo Nacional de Ciencias Naturales, CSIC. Jose Gutierrez Abascal, 2. E-28006, Madrid, Spain. (lario@ mncn.csic.es) - A. J. Plater, Dep. Geography, University of Liverpool. P. O. Box 147, L69 3BX Liverpool, UK. - J. L. Goy \& F. J. Srerro, Dep. Geologia, Universidad de Salamanca. E-37008 Salamanca, Spain. - C. J. Dabrio, Dep. Estratigrafía, Facultad de Geología, Universidad Complutense, E-28040 Madrid, Spain. - F. Borja, Area Geografía Fisica, Universidad de Huelva, Campus del Carmen, E-21007 Huelva, Spain. 